\section{Impact of Janus kinase inhibitors on the risk of cardiovascular events in patients with rheumatoid arthritis: systematic review and meta-analysis of randomised controlled trials}

We read with great interest the article by Xie and colleagues ${ }^{1}$ regarding the impact of Janus kinase inhibitors (Jakinibs) on the risk of cardiovascular events in patients with rheumatoid arthritis (RA). This systematic review and meta-analysis revealed no significant change in cardiovascular risks for Jakinib-treated patients with RA in a short-term perspective study. However, some methodological issues must be addressed. First, Cochran $\mathrm{Q}$ is the weighted sum of squares on a standardised scale, and when it is reported with low $\mathrm{p}$ values, it indicates heterogeneity. ${ }^{2}$ However, care must be taken when interpreting the $\chi^{2}$ test results because it has low power in the common situation of a meta-analysis, especially when studies have a small sample size or few cases. While a statistically significant result may indicate a problem with heterogeneity, a non-significant result must not be considered evidence of no heterogeneity. Although no definitive cut-off value has been established at which no data pooling should be performed, a $\mathrm{p}$ value of 0.10 , rather than the conventional level of 0.05 , is usually used to determine statistical significance. ${ }^{2}$ Second, two statistical models can be used for meta-analyses: the fixed-effects model and the random-effects model. The selection of the appropriate model is important to ensure that various statistics are estimated correctly. ${ }^{3}$ The choice of the meta-analysis method should be explained, and a rationale for choosing the statistical model should also be stated. ${ }^{4}$ The fixed-effects model is generally used in the absence of heterogeneity in a meta-analysis that includes a large number of studies, preferably with large sample sizes. If heterogeneity is a concern, the random-effects model has been advocated for data pooling. A high heterogeneity was detected among the three kinds of Jakinibs for venous thromboembolism events $\left(I^{2}=63.5 \%\right)$ and all cardiovascular events $\left(I^{2}=71.7 \%\right){ }^{1}$ Considering the substantial and considerable heterogeneity, the random-effects model would be the more appropriate choice in those cases. A random-effects meta-analysis may be used to incorporate heterogeneity among studies. ${ }^{5}$ However, this is not a substitute for a thorough investigation of heterogeneity. ${ }^{4}$ Exploration of possible causes of heterogeneity is always advisable. Thus, we believe that the findings of this study should be interpreted with consideration of the aforementioned methodological concerns.

\section{Young Ho Lee, ${ }^{\circledR}$ Gwan Gyu Song}

Department of Rheumatology, Korea University, Seongbuk-gu, , Korea (the Republic of)

Correspondence to Professor Young Ho Lee, Rheumatology, Korea University, Seoul 02841, Korea; lyhcgh@korea.ac.kr

Correction notice This article has been corrected since it published Online First. The title has been corrected.

Funding The authors have not declared a specific grant for this research from any funding agency in the public, commercial or not-for-profit sectors.

Competing interests None declared.

Patient consent for publication Not required.

Provenance and peer review Not commissioned; internally peer reviewed.

(c) Author(s) (or their employer(s)) 2019. No commercial re-use. See rights and permissions. Published by BMJ.

\section{Check for updates}

To cite Lee YH, Song GG. Ann Rheum Dis Epub ahead of print: [please include Day Month Year]. doi:10.1136/annrheumdis-2019-215815

Received 31 May 2019

Accepted 2 June 2019

Ann Rheum Dis 2019;0:1. doi:10.1136/annrheumdis-2019-215815

\section{REFERENCES}

1 Xie W, Huang Y, Xiao S, et al. Impact of Janus kinase inhibitors on risk of cardiovascular events in patients with rheumatoid arthritis: systematic review and meta-analysis of randomised controlled trials. Ann Rheum Dis 2019.

2 Higgins JPT, Thompson SG, Deeks JJ, et al. Measuring inconsistency in meta-analyses. BMJ 2003;327:557-60.

3 Borenstein $M$, Hedges LV , Higgins JPT, et al. A basic introduction to fixed-effect and random-effects models for meta-analysis. Res Synth Methods 2010;1:97-111.

4 Collaboration C. Cochrane Handbook for systematic reviews of interventions 5.0. 0: cochrane collaboration, 2008.

5 DerSimonian R, Laird N. Meta-analysis in clinical trials. Control Clin Trials 1986;7:177-88. 